\title{
The Effectiveness of Lumbricus rubellus Extract Toward Interleukin-10 and Immunoglobulin E and Atopic Dermatitis Scoring Index (SCORAD)
}

\author{
Farida Tabri*(i), Pipim Septiana Bayasari(D), Rosani Sri Camelia Nurdin, (iD, Anis Irawan Anwar (D), Anni Adriani(i), Farida llyas (iD
}

Department of Dermatology and Venereology, Hasanuddin University, Makassar, Indonesia

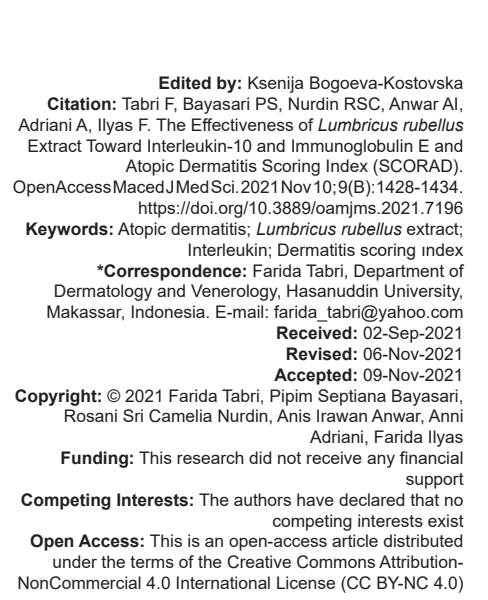

\begin{abstract}
BACKGROUND: Atopic dermatitis (AD) is a chronic inflammatory skin condition characterized by severe pruritic symptoms and chronic $A D$ related to clinical features in form of lichenification associated with a history of atopic disease both for himself and family.

AIM: This study aims to determine the effectiveness of using earthworm extract (Lumbricus rubellus) to increase interleukin (IL)-10 and decrease immunoglobulin $E$ (IgE), and to describe the AD (SCORAD) scoring index of patients with $A D$

METHODS: This research used quantitative with quasi experiment method. The data were analyzed using SPSS v19 program. To determine the basic characteristics of numerical variables, the mean standard deviation is functioned if the data distribution amount is even, if it is not, it used the median. Meanwhile, to observe the relationship between L. rubellus extract and IgE, Mann-Whitney test analysis (U-Test) was used

RESULTS: The results of this study indicate that the administration of $L$. rubellus extract showed a changes and differences before and after being involved with the extract. IgE levels between ERL and no ERL groups had differences $(p<0.05)$, however on day 15 both groups did not show any differences. Meanwhile, the SCORAD index indicated that the influence of lumbricus rebellus extract has an effect on low number of AD patients.
\end{abstract}

CONCLUSION: It can be concluded that the administration of $L$. rubellus extract in patients with AD is quite effective.

\section{Introduction}

Atopic dermatitis (AD) is a chronic inflammatory skin disease that often occurs in children. It is characterized by symptoms of pruritus and dry skin. This disease is often associated with genetic factors, impaired skin barrier function, allergen sensitization, and recurrent skin infections, and is often associated with increased serum levels of immunoglobulin $E(\operatorname{lgE})$ and a personal or family history of atopy [1]. According to the International Study of Asthma and Allergies in Childhood, AD has a prevalence that varies from $0.3 \%$ to $20.5 \%$ in 56 countries [2], [3]. Nutten (2016) explained that the incidence of $A D$ is estimated to occur around $15-20 \%$ in children and $1-3 \%$ in adults worldwide, and has increased by 2-3 times over the past decade [4]. According to the Indonesian Child Dermatology Study Group (KSDAI) In Indonesia, $A D$, ranks in the top 10 of other skin diseases, which obtained $23.67 \%$ of cases [5]. AD is divided into two groups, intrinsic and extrinsic types. The intrinsic type of $A D$ has normal IgE levels and is not associated with other atopic diseases compared to the extrinsic type, which requires intermediate sensitization by $\operatorname{lgE}$. IgE-mediated sensitization is usually associated with bronchial asthma or allergic rhinoconjunctivitis and has a positive response to both food and environmental allergens [6]. There are two involved hypotheses in the pathogenesis of $A D$ [7]. The first hypothesis stated that there is a disruption of skin epithelial cells that causes disruption on the function of skin barrier function and has an effect on immune response. The second hypothesis suggests an abnormal immune response that causes in the predominance of T helper 2 (TH2) and IgE cells.

The pathophysiology of $A D$ is multifactorial involving disruption of the skin barrier, changes in the immune response mediated by cellular and humoral immune systems, and the hypersensitivity reactions of type I that lead to increased IgE [8]. Human T cells are categorized into T helper 1 (Th1) cells and TH2 cells it depends on the produced cytokine profile. The exposure to antigen that happens in continuity will change the cytokine profile in skin lesions from Th1 to TH2 [9]. The pathophysiology of $A D$ occurs due to several mechanisms, one of the dominant mechanisms is inflammation. This process occurs due to $\mathrm{TH} 2$ cells that are associated with cytokines such as IL-4 and IL-13, 
and chemokines such as TARC (thymus and activationregulated chemokine) and eotaxy. TH2 cytokines of IL-4 and IL-13 stimulate fibroblasts to produce periostine, a protein that causes keratinocytes to produce TSLP, it induces the production of TARC/CCL17 by dendritic cells [10]. High levels of IL-4 that produced by $T$ cells during human birth can increase the risk of developing AD. The European Task Force on AD created an index which known as Scoring Atopic Dematitis (SCORAD) to assess the degree of inflammation on AD [5].

One of the natural ingredients that can be used as additional medicine is an earthworm extract of Lumbricus rubellus. Earthworm (Lumbricus sp) extract contains antibacterial properties that can inhibit the growth of pathogenic bacteria, such as gram-positive and gram-negative bacteria [11]. Kiss et al. (2020) in their research stated that worms induce a stereotypical TH2 immune response, characterized by the existence of IL-4, IL-5, IL-3, and IL-10 cytokines, antibody isotopes $\lg$ 1, IgG4, and $\operatorname{lgE}$ [12]. It is supported by Taylor et al. (2012) who found that worm-infected patients can stimulate the formation of IL-10 and transforming growth factor-beta (TGF- $\beta$ ) through an increase of $T$ regulatory cells [13]. The Increased of IL-10 and TGF- $\beta$ can reduce the increased $\mathrm{TH} 2$ cells in $A D$ patients. IL-10 has the main function of preventing extensive tissue damage after the inflammation and infection [14].

However, until today no one has researched the use of earthworms in AD, even though earthworms have many available extract. Thus, this study aims to determine the effectiveness of using earthworm extract on increasing IL-10 and reducing IgE in AD patients, moreover, it has an aim to describe the SCORAD index.

\section{Material and Methods}

This study uses quasi-experimental research type with pretest and posttest within the control group design. Pretest and posttest are research designs. Quasi-experimental research is research similar to experimental research but not real experimental research. Although the independent variables are manipulated, participants will not be randomly assigned to conditions or order of conditions [15]. Pretest was done before being given treatment and posttest was done after being given treatment, therefore the obtained results will be more accurate. The study was conducted during February 2020 to September 2020 at Dermatology and Venereology Polyclinic of Pendidikan Hospital that affiliated with the Department of Dermatology and Venereology, Hasanuddin University. The population of this study was every patients who met the criteria of inclusion. The Samples were taken collectively since the patient came for treatment at Dermatology and Venereology Polyclinic that was diagnosed with AD. There were 30 samples collected then divided into two groups, (a) the intervention group with $L$. rubellus extract and (b) the control group without L. rubellus extract.

For adult, the specimen was taken directly from patient's blood intravenously. As for the serum specimens of pediatric patients, it was taken after the parents signed the informed consent. A clinical examination was then performed to confirm the diagnosis by SCORAD index. Furthermore, to check the levels of IL-10 and IgE in patient, a blood specimen or blood sample of $5 \mathrm{cc}$ was taken. The blood sample is then divided into three tubes of sample. Samples 1 and 2 were put into a tube containing EDTA to collect blood plasma, while sample 3 was put into a micro centrifuge tube without EDTA to collect serum. Furthermore, those three blood samples were centrifuged to separate blood plasma and blood serum from the cells. Total IgE examination was carried out using the EnzymeLinked Immunosorbent Assay (ELISA) method (the ELISA kit for total Human IgE) to observe the total $\lg E$ concentration of the examined blood samples.

The collected data were then analyzed by SPSS v.19 program. To determine the basic characteristics of numerical variables, the mean standard deviation was used if the data distribution is even, otherwise, it used the median. It is used to observe the basic numerical data, mean standard deviation is used if the data distribution is evenly distributed. To observe the relationship between earthworm extract ( $L$. rubellus) and IL-10, paired T-Test analysis was used, while to observe the effect on IgE, U-Test was used.

The observations on patients were carried out to determine the severity of $A D$ and the occurred side effects. The patients are also obtained several advice as they consume $L$. rubellus extract within the following details;

a. Dosage for children of 1-3-years-old $(2 \times 250 \mathrm{mg})$

b. Dosage for children of >3-12-years-old $(2 \times 500 \mathrm{mg})$

c. Dosage for adult within the amount of $(2 \times 1000 \mathrm{mg})$ for 7 days.

This research has been declared as ethically feasible by the ethics committee of biomedical research of humans at Hasanuddin University Medical Faculty and Hasanuddin University General Teaching Hospital Makassar within the ethical approval number of 125/UN4.6.4.5.31/PP36/2020.

\section{Results}

In order to determine the effect of $L$. rubellus extract on $\lg E$ and $A D$ (SCORAD) scoring index, it is 
necessary to conduct direct research on each research subjects, which consist of the patients with $A D$ who are divided into two groups. The first group (X) was a control group consisting of the patients with $A D$ and the second group (B) patients with $A D$ who were given L. rubellus extract. Both groups were monitored for $\lg E$ and SCORAD levels on day 0 , day 8 and day 15 . Both of the groups were monitored for $\lg E$ and SCORAD levels on day 0 , day 8 , and day 15 . The number of male subjects is more than the number of female samples, with a ratio of $3: 2$, and most of the age group is $25-44$-years-old $(50 \%)$ followed by the age group of 5-14 years $(30 \%)$.

Before begin the difference test, it is required to test the normality test and homogeneity test. Homogeneity test was carried out to find out the obtained data from the two groups that had homogeneous variants or not, and the obtained results from the data of both groups, the intervention group and the control group, were not homogeneous within the Asymp value. Sig. (2-tailed) 0.05. Based on the two previous tests above, the obtained data from both groups, control group and intervention group, were not normally distributed and not homogeneous, therefore the hypothesis testing used non-parametric testing, the Mann-Whitney Test (U-Test) and the Wilcoxon test.

\section{The difference of IL-10 levels in $A D$ patients of the two groups at day 0,8 , and 15}

To assess the effect of $L$. rubellus extract on IL-10 in AD patients, the Mann-Whitney test (U-Test) was conducted to determine whether there was a difference between two different treatments (treated with $L$. rubellus extract and not treated with $L$. rubellus extract) or not on day 0,8 , and 15 . The results of the Mann-Whitney test can be seen in Table 1.

Based on Table 1 and Figure 1, it can be seen that in the Mann-Whitney test, there is a difference $(p<0.05)$ in IL-10 levels between ERL group and the group without ERL on day 0 and day 8 , however it is different on day 15 there are no differences $(p>0.05)$ of IL-10 levels in ERL group and the group without ERL.

To assess the difference in IL-10 levels between pretest and posttest application of $L$. rubellus extract at $\mathrm{HO}$ (before application), H8 (8 ${ }^{\text {th }}$ day after application), and $\mathrm{H} 15$ (1 $15^{\text {th }}$ day after application) it used
Wilcoxon test. The results of Wilcoxon test can be seen in Tables 2 and 3.

Based on Tables 2 and 3, it can be seen that in the Wilcoxon test of the ERL group, there is no difference $(p>0.05)$ in IL-10 levels before and after the application of $L$. rubellus extract at $\mathrm{HO}$ (before application), day 8 (8 days after application), and day 15 (15 days after absorption). In a group without ERL, there was also no difference $(p>0.05)$ of IL-10 levels on days 0,8 , and 15 .

Based on Table 4 and Figure 2, it can be seen in Mann-Whitney test that there is a difference $(p<0.05)$ in IgE levels between the ERL group and the group without ERL on day 0 and day 8, however on day 15 it shows different result, there are no difference $(p>0.05) \lg E$ levels on a group with $E R L$ and a group without ERL.

To assess the difference of IgE levels before and after the application of $L$. rubellus extract at day 0 (before application), day 8 ( $8^{\text {th }}$ day after application), and day $15\left(15^{\text {th }}\right.$ day after application) it used Wilcoxon test. The results of the test by Wilcoxon test can be shown in Tables 5 and 6.

Based on Tables 5 and 6 , it can be seen that, based on Wilcoxon test in ERL group, there was no difference $(p>0.05)$ in lgE levels before and after the application of $L$. rubellus extract at day 0 (before application), day 8 ( $8^{\text {th }}$ day after application), and day 15 ( $15^{\text {th }}$ day after absorption). In a group without ERL, there was no difference ( $p>0.05$ ) in IgE levels on day 0,8 and 15. The results of the Scored Patient sample who consume $L$. rubellus extract on day 0 , day 8 and day 15 can be seen in the following Table 7.

Meanwhile, for patients who did not consume L. rubellus extract, the SCORAD value of each patient on each day describes a different situation. The results above illustrate that mild AD has SCORAD index under 15. It has a characteristic such as skin discoloration to redness, mild dry skin, mild itchy skin, and there is no secondary infection. Medium AD has SCORAD index between 15 until 40 . It has several characteristics such as: skin redness, mild or medium skin infection, itching, sleep disturbances, and lichenification. The last is, severe AD has SCORAD index more than 40 . It has several characteristic such as: skin redness, itching, lichenification, sleep disturbances, and severe skin infections. According to the Table 7, there are differences

Table 1: The differences in IL-10 levels patients with atopic dermatitis in two groups

\begin{tabular}{|c|c|c|c|c|c|c|c|}
\hline \multirow[t]{2}{*}{ Treatment } & \multicolumn{6}{|c|}{ Mann-Whitney test } & \multirow[t]{2}{*}{ Description } \\
\hline & Min & Max & Mean & Standard deviation & Median & $p$ & \\
\hline \multicolumn{8}{|l|}{ IL-10 (H0) } \\
\hline ELR & 64.39 & 119.48 & 77.3157 & 15.45106 & 70.5219 & \multirow[t]{2}{*}{0.010} & \multirow[t]{2}{*}{ Different } \\
\hline Without ELR & 64.74 & 1802.47 & 219.7086 & 439.96753 & 102.1230 & & \\
\hline \multicolumn{8}{|l|}{$\mathrm{IL}-10(\mathrm{H} 8)$} \\
\hline ELR & 65.61 & 137.05 & 83.1810 & 20.33293 & 75.5281 & \multirow[t]{2}{*}{0.006} & \multirow[t]{2}{*}{ Different } \\
\hline Without ELR & 73.19 & 226.66 & 118.0581 & 47.20522 & 108.2801 & & \\
\hline \multicolumn{8}{|l|}{ IL-10 (H15) } \\
\hline ELR & 63.70 & 224.84 & 103.2225 & 49.54104 & 85.2536 & \multirow[t]{3}{*}{0.395} & \multirow[t]{3}{*}{ There is no difference } \\
\hline Without ELR & 64.91 & 570.09 & 116.0181 & 131.49605 & 70.8765 & & \\
\hline Without ELR & 1.50 & 12.00 & 5.2933 & 3.09619 & 4.9000 & & \\
\hline
\end{tabular}


between patients who consume $L$. rubellus extract and patients who did not consume lumbricus extract.

\section{SCORAD index before and after the} application of $L$. rubellus extract

Based on the difference of the average of SCORAD index above, it can be seen that there is a difference in the average SCORAD index between the patients that obtain $L$. rubellus extract (ELR) and patients who did not obtain lumbricus extract (no ELR). It is explained that on day 0 , patients given lumbricus extract obtained a slightly higher SCORAD index with 11.9. The SCORAD index for is slightly reduced on day $8^{\text {th }}$ and day $15^{\text {th }}$ for 11.4 and 10.8 . Meanwhile, on the

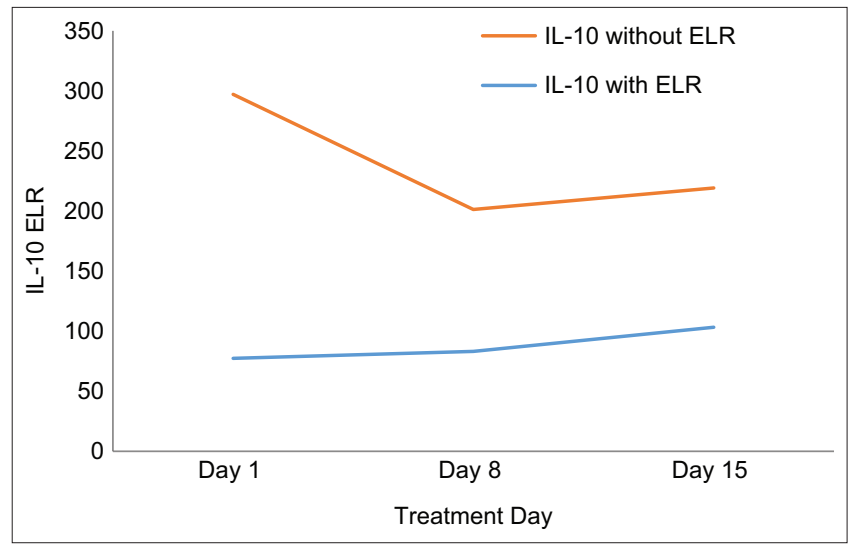

Figure 1: Interleukin-10 levels in two control and intervention groups on day 1,8 , and 15 day $8^{\text {th }}$ of patients without $L$. rubellus extract obtained a higher score index for 11.46 but it is reduced on the day $15^{\text {th }}$ for 11.2 .

These results indicate that the involvement of lumbricus extract cause an effect on the SCORAD index level of $A D$ patients. The lower the index value, the minor suffered disease. Obtaining lumbricus extract tends to affect the SCORAD index levels to be lower than patients without $L$. rubellus extract.

\section{Discussion}

$A D$ is a residual chronic disease characterized by clinical symptoms of itching, usually affecting children. The pathogenesis of $A D$ includes skin barrier disorders, such as the destruction of filaggrin gene expression, genetic, environmental, and immune system abnormalities. The destruction of the skin's protective structure will reduce the ability and function of the skin, causing immune and inflammatory reactions [16]. The function of the skin barrier can minimize the loss of moisture from the epidermis and protect it from external factors, such as; heat or cold, penetration of potentially harmful substances, and colonization of pathological bacteria [17]. Both the natural and innate immune system contribute to the pathogenesis of AD. TH2 cells play an important role in increasing the IgE patients with $A D$. Kay (2001) explained that in acute AD lesions, the release of

Table 2: The differences in IL-10 levels between before and after the application of ELR on day 0 , 8, and 15

\begin{tabular}{|c|c|c|c|c|c|c|}
\hline & Mean & $\mathrm{N}$ & SD & SEM & Sig. Wilcoxon & Description \\
\hline \multicolumn{7}{|l|}{ Pair 4} \\
\hline IL-10 ELR (H8) & 83.1810 & 15 & 20.33293 & 5.24994 & \multirow[t]{2}{*}{0.156} & \multirow[t]{2}{*}{ There is no differences } \\
\hline IL-10 ELR (H1) & 77.3157 & 15 & 15.45106 & 3.98945 & & \\
\hline \multicolumn{7}{|l|}{ Pair 5} \\
\hline IL-10 ELR (H15) & 103.2225 & 15 & 49.54104 & 12.79144 & \multirow[t]{2}{*}{0.140} & \multirow[t]{2}{*}{ There is no differences } \\
\hline IL-10 ELR (H1) & 77.3157 & 15 & 15.45106 & 3.98945 & & \\
\hline \multicolumn{7}{|l|}{ Pair 6} \\
\hline IL-10 ELR (H15) & 103.2225 & 15 & 49.54104 & 12.79144 & \multirow[t]{2}{*}{0.281} & \multirow[t]{2}{*}{ There is no differences } \\
\hline IL-10 ELR (H8) & 83.1810 & 15 & 20.33293 & 5.24994 & & \\
\hline
\end{tabular}

Table 3: Differences in IL-10 levels for patient without application of ELR on day 0, 8, and 15

\begin{tabular}{|c|c|c|c|c|c|c|}
\hline & Mean & $\mathrm{N}$ & Std. Deviation & Std. Error Mean & Sig. Wilcoxon & Description \\
\hline \multicolumn{7}{|l|}{ Pair 4} \\
\hline IL-10 Without ELR (H8) & 118.0581 & 15 & 47.20522 & 12.18834 & \multirow[t]{2}{*}{0.820} & \multirow[t]{2}{*}{ There is no differences } \\
\hline IL-10 Without ELR (H1) & 219.7086 & 15 & 439.96753 & 113.59913 & & \\
\hline \multicolumn{7}{|l|}{ Pair 5} \\
\hline IL-10 Without ELR (H15) & 116.0181 & 15 & 131.49605 & 33.95213 & \multirow[t]{2}{*}{0.036} & \multirow[t]{2}{*}{ Different } \\
\hline IL-10 Without ELR (H1) & 219.7086 & 15 & 439.96753 & 113.59913 & & \\
\hline \multicolumn{7}{|l|}{ Pair 6} \\
\hline IL-10 Without ELR (H15) & 116.0181 & 15 & 131.49605 & 33.95213 & \multirow[t]{2}{*}{0.078} & \multirow[t]{2}{*}{ There is no differences } \\
\hline IL-10 Without ELR (H8) & 118.0581 & 15 & 47.20522 & 12.18834 & & \\
\hline
\end{tabular}

IL-10: Interleukin-10, ELR: Lumbricus rubellus extract.

Table 4: The differences in IgE levels of atopic dermatitis patients in a group with ERL and without ERL

\begin{tabular}{|c|c|c|c|c|c|c|c|}
\hline \multirow[t]{2}{*}{ Treatment } & \multicolumn{6}{|c|}{ Mann-Whitney Test } & \multirow[t]{2}{*}{ Description } \\
\hline & Min & Max & Mean & Standard Deviation & Median & $p$ & \\
\hline \multicolumn{8}{|l|}{$\operatorname{lgE}(\mathrm{H} 0)$} \\
\hline ELR & 175.46 & 1057.21 & 576.1896 & 255.78367 & 513.9254 & \multirow[t]{2}{*}{0.001} & \multirow[t]{2}{*}{ Different } \\
\hline Without ELR & 58.99 & 521.13 & 230.1328 & 162.60585 & 199.9720 & & \\
\hline \multicolumn{8}{|l|}{$\lg \mathrm{E}(\mathrm{H} 8)$} \\
\hline ELR & 82.72 & 996.37 & 440.8090 & 315.38880 & 379.3188 & \multirow[t]{2}{*}{0.059} & \multirow[t]{2}{*}{ Different } \\
\hline Without ELR & 60.90 & 457.38 & 232.4674 & 142.84166 & 199.2657 & & \\
\hline \multicolumn{8}{|l|}{$\lg \mathrm{E}(\mathrm{H} 15)$} \\
\hline ELR & 37.33 & 816.47 & 370.3055 & 262.32755 & 294.3760 & \multirow[t]{2}{*}{0.272} & \multirow[t]{2}{*}{ There is no differences } \\
\hline Without ELR & 89.77 & 781.19 & 257.5831 & 192.89845 & 173.4884 & & \\
\hline
\end{tabular}


$\mathrm{TH} 2$ is characterized by the dermal infiltration of CD4+ T cells and eosinophils. It can increase the expression of cytokines IL-4, IL-5, and IL-13 by increasing eosinophilderived products form, and IFN- is rarely expressed [18]. In chronic $A D$, there is a transition from $\mathrm{TH} 2$ to $\mathrm{TH} 1$, the expression of IFN- $\gamma$, IL-12, GM-CSF, and tissue remodeling increase, collagen deposition increases and skin thickens. Specific antigens that can penetrate the skin due to skin barrier barriers are captured by antigenspecific IgE on inflammatory dendritic epidermal cells and Langerhans cells (LC). Specific IgE mainly reacts in the environment and bacterial antigens. The LC of $A D$ patients mainly secretes the $\mathrm{TH} 2$ cytokine $\mathrm{IL}-10$, not the TH1 cytokine IL-12 [19].

The role of cytokines in $A D$ begins with an adaptive immune response mediated by $\mathrm{T}$ cells and $B$ cells and associated with Antigen Presenting Cells (APC). The adaptive immune system consists of cellular and humoral immune system [19]. T cells are produced in the bone marrow and grow in the thymus. The $T$ Cell Receptor will recognize a specific peptide that binds to the Major Histocompatibility Complex (MHC)/Human Leukocyte Antigen, which is the cell surface molecule of the infected APC. This combination

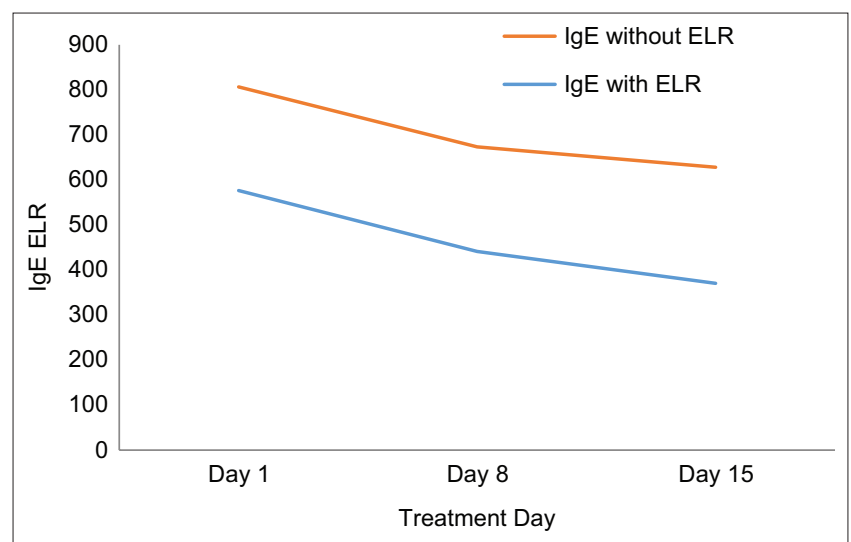

Figure 2: Immunoglobulin E levels in two control intervention groups on day 1,8 , and 15 activates $\mathrm{T}$ cell proliferation. In AD, MHC class II within lymphoid tissues works by removing proteins that are present in lysosomes, endosomes, or extracellularly. T lymphocytes secrete cytokines to help T cells, B cells, and macrophages, thereby activating $\mathrm{T}$ helper cells (CD4). TH1 cells play a major role in the activation of macrophages. $\mathrm{TH} 1$ cells produce the cytokine profile IL-2 (T-cell proliferation) and IFN- $\gamma$ (stimulate and activate the NK cells), while dominant $\mathrm{TH} 2$ cells are associated with activation of $\mathrm{B}$ cells and production of antibody. TH2 cells produce cytokine profiles IL-4, IL-5 (synthesizing IgE and activating eosinophils), and IL-10 (inhibiting profliferation of $\mathrm{TH} 1$ ).

Allergens are captured by dendritic cells and presented to $\mathrm{T}$ cells. This will cause an imbalance between $\mathrm{TH} 1$ and $\mathrm{TH} 2$ cells. $\mathrm{TH} 2$ cells induce $\mathrm{B}$ cells to produce IgE. Allergen-specific lgE binds to $\lg \mathrm{E}$ (FceRI) receptors on mast cells [18]. The production of IgE by $B$ cells in atopic diseases depends on the support of TH2 cells, which produce IL-4, IL-5, IL-9, and IL-3. Mostly, TH1 cells promote cellular immune responses rather than humoral immune responses and play a greater role in chronic infections [20]. However, re-exposure to similar allergens in sensitive mucous membranes will cause the IgE molecules on mast cells to bind to the allergens, and stimulate mucosal mast cells to have degranulation by releasing histamine, leukotriene, heparin, and other toxic products [18]. Yusriana (2008) stated that alkaloid compounds in $L$. rubellus contain nitrogen atoms and have alkaline characteristics with $\mathrm{pH}>7$, which also have antibacterial and antipyretic effects. The mechanism in inhibiting the bacterial growth is by interfering the constituent components of peptidoglycan with the bacterial cells [21]. Therefore the cell wall cannot be formed completely.

In the results of the study, there was a difference between the ERL group and the non-ERL group on the $8^{\text {th }}$ day of ERL administration $(p<0.05)$. Although there was no significant difference on the $15^{\text {th }}$ day but there was an increase in IL levels 10 and reduction in IgE.

Table 5: The Differences in IgE levels before and after the application of ELR on day 0, 8, and 15

\begin{tabular}{|c|c|c|c|c|c|c|}
\hline & Mean & $\mathrm{N}$ & Std. Deviation & Std. Error Mean & Sig. Wilcoxon & Description \\
\hline \multicolumn{7}{|l|}{ Pair 7} \\
\hline $\operatorname{lgE}$ ELR (H8) & 440.8090 & 15 & 315.38880 & 81.43304 & \multirow[t]{2}{*}{0.191} & \multirow[t]{2}{*}{ There is no differences } \\
\hline $\lg E$ ELR (H1) & 576.1896 & 15 & 255.78367 & 66.04306 & & \\
\hline \multicolumn{7}{|l|}{ Pair 8} \\
\hline IgE ELR (H15) & 370.3055 & 15 & 262.32755 & 67.73268 & \multirow[t]{2}{*}{0.100} & \multirow[t]{2}{*}{ There is no differences } \\
\hline $\lg E \operatorname{ELR}(\mathrm{H} 1)$ & 576.1896 & 15 & 255.78367 & 66.04306 & & \\
\hline \multicolumn{7}{|l|}{ Pair 9} \\
\hline IgE ELR (H15) & 370.3055 & 15 & 262.32755 & 67.73268 & \multirow[t]{2}{*}{0.460} & \multirow[t]{2}{*}{ There is no differences } \\
\hline $\operatorname{lgE}$ ELR (H8) & 440.8090 & 15 & 315.38880 & 81.43304 & & \\
\hline
\end{tabular}

IgE: Immunoglobulin E, ELR: Lumbricus rubellus extract.

Table 6: The Differences in IgE levels on a group without the application of ELR day 0, 8, and 15

\begin{tabular}{|c|c|c|c|c|c|c|}
\hline & Mean & $\mathrm{N}$ & Std. Deviation & Std. Error Mean & Sig. Wilcoxon & Description \\
\hline \multicolumn{7}{|l|}{ Pair 7} \\
\hline IgE Without ELR (H8) & 232.4674 & 15 & 142.84166 & 36.88156 & 0.776 & There is no differences \\
\hline IgE Without ELR (H1) & 230.1328 & 15 & 162.60585 & 41.98465 & & \\
\hline \multicolumn{7}{|l|}{ Pair 8} \\
\hline IgE Without ELR (H15) & 257.5831 & 15 & 192.89845 & 49.80617 & 0.865 & There is no differences \\
\hline IgE Without ELR (H1) & 230.1328 & 15 & 162.60585 & 41.98465 & & \\
\hline \multicolumn{7}{|l|}{ Pair 9} \\
\hline IgE Without ELR (H15) & 257.5831 & 15 & 192.89845 & 49.80617 & 0.733 & There is no differences \\
\hline IgE Without ELR (H8) & 232.4674 & 15 & 142.84166 & 36.88156 & & \\
\hline
\end{tabular}


Table 7: SCORAD index samples of patients who consumed and not consumed ELR on Day 0, day 8 and day 15

\begin{tabular}{llllllll}
\hline & Day 0 & Day 8 & Day 15 & & Day 0 & Day 8 & Day 15 \\
\hline ELR-1 & 10 & 10 & 9 & No ELR-1 & 12 & 12 & 12 \\
ELR-2 & 13 & 12 & 12 & No ELR-2 & 11 & 10 & 10 \\
ELR-3 & 11 & 11 & 10 & NO ELR-3 & 10 & 9 & 9 \\
ELR-4 & 12 & 12 & 10 & NO ELR-4 & 12 & 12 & 11 \\
ELR-5 & 13 & 11 & 11 & NO ELR-5 & 12 & 11 & 11 \\
ELR-6 & 14 & 14 & 12 & NO ELR-6 & 11 & 10 & 10 \\
ELR-7 & 13 & 12 & 12 & NO ELR-7 & 10 & 11 & 10 \\
ELR-8 & 10 & 10 & 10 & NO ELR-8 & 13 & 12 & 12 \\
ELR-9 & 11 & 10 & 11 & NO ELR-9 & 14 & 14 & 14 \\
ELR-10 & 14 & 13 & 12 & NO ELR-10 & 11 & 12 & 12 \\
ELR-11 & 12 & 12 & 11 & NO ELR-11 & 14 & 14 & 12 \\
ELR-12 & 12 & 11 & 11 & NO ELR-12 & 13 & 12 & 12 \\
ELR-13 & 11 & 10 & 10 & NO ELR-13 & 10 & 10 & 10 \\
ELR-14 & 10 & 11 & 10 & NO ELR-14 & 11 & 10 & 11 \\
ELR-15 & 13 & 12 & 12 & NO ELR-15 & 14 & 13 & 12 \\
\hline SCOR-D & & 12 & & & 12 & &
\end{tabular}

The side effects that occurred during the study were intestinal diseases, such as nausea and intestinal diseases. Deworming therapy (or the use of $L$. rubellus extract) can be used as an adjuvant treatment for allergic patients. It showed that the rural population is severely infected with helminths and the prevalence of allergic diseases is low. It has been proved through animal model studies that it inhibits IL by stimulating the formation of TGF $\beta$ and IL-10.

\section{Conclusion}

Based on the analysis above, $L$. rubellus extract is quite effective to be given to AD patients. $L$. rubellus extract can stimulate the construction of $\mathrm{IL}-10$ and suppress $\mathrm{TH} 2$ cells to reduce $\lg$ in $\mathrm{AD}$ patients. It can be seen from the ability of lumbricus extract to increase IL-10 levels and decrease $\lg E$ on day 0 , day 8 , and day 15 although it is not really significant. Furthermore, the results of the SCORAD Index indicated that the distribution of $L$. rubellus extract has an effect on low levels of SCORAD index. $L$. rubellus extract can reduce the SCORAD index levels in $A D$ patients which concluded that the lower patient's SCORAD index, the better patient's condition.

After conducting the research and concluding the results, for further research, the authors suggest to examine the side effects of the long-term distribution of L. rubellus extract in patients with $\mathrm{AD}$ disease.

\section{What is known about this topic}

1. $\quad A D$ is a chronic inflammatory skin condition characterized by severe pruritic symptoms.

2. Earthworm (L. rubellus) extract contains antibacterial properties that can inhibit the growth of pathogenic bacteria.

\section{What this study adds}

1. L. rubellus extract can stimulate the construction of IL-10 and suppress TH2 cells to reduce $\lg E$ in $A D$ patients.

2. SCORAD Index used to indicate the effect of L. rubellus extract to atomic dermatitis patients.

\section{References}

1. Leung DY. New insights into atopic dermatitis: Role of skin barrier and immune dysregulation. Allergol Int. 2013;62(2):151-61. https://doi.org/10.2332/allergolint.13-RAl-0564

PMid:23712284

2. Bieber T. Atopic dermatitis. Ann Dermatol. 2010;22(2):125. https://doi.org/10.5021/ad.2010.22.2.125 PMid:20548901

3. Zheng T. The atopic march: Progression from atopic dermatitis to allergic rhinitis and asthma. J Clin Cell Immunol. 2014;5(2):202. https://doi.org/10.4172/2155-9899.1000202 PMid:25419479

4. Nutten S. Atopic dermatitis: Global epidemiology and risk factors. Ann Nutr Metab. 2015;66 Suppl 1:8-16. https://doi. org/10.1159/000370220

PMid:25925336

5. Evina B. Clinical manifestations and diagnostic criteria of atopic dermatitis. J Major. 2015;4(4):23-30.

6. Tokura Y. Extrinsic and intrinsic types of atopic dermatitis. J Dermatol Sci. 2010;58(1):1-7. https://doi.org/10.1016/j. jdermsci.2010.02.008 PMid:20207111

7. Watson W, Kapur S. Atopic dermatitis. Allergy Asthma Clin Immunol. 2011;7 Suppl 1:S4. https://doi. org/10.1186/1710-1492-7-S1-S4

PMid:22166055

8. Madhu R. Management of atopic dermatitis. Indian J Pract Pediatr. 2015;17(3):242-8.

9. Mizutani H. Cytokines in atopic dermatitis (Eczema). In: Handbook of Atopic Eczema. Berlin, Heidelberg: Springer; 2006. p. 350-6.

10. Katayama I, Aihara M, Ohya Y, Saeki H, Shimojo N, Shoji S, et al. Japanese guidelines for atopic dermatitis 2017. Allergol Int. 2017;66(2):230-47. https://doi.org/10.1016/j.alit.2016.12.003 PMid:28209325

11. Foekh NP, Sukrama ID, Lestari AA. The ability of earthworm Lumbricus rubellus extract in slowing down the activation of NFkB and TNF- $\alpha$ in lipopolysaccharide-induced Rattus norvegicus. Bali Med J. 2019;8(2):439.

12. Kiss M, Burns H, Donnelly S, Hawthorne WJ. Effectiveness of helminth therapy in the prevention of allograft rejection: A systematic review of allogeneic transplantation. Front Immunol. 2020;11:1604. https://doi.org/10.3389/fimmu.2020.01604 PMid:32849543

13. Taylor MD, van der Werf N, Maizels RM. T cells in helminth infection: The regulators and the regulated. Trends Immunol. 2012;33(4):181-9. https://doi.org/10.1016/j.it.2012.01.001 PMid:22398370

14. Boyman $\mathrm{O}$, Werfel T, Akdis CA. The suppressive role of IL-10 in contact and atopic dermatitis. J Allergy Clin Immunol. 2012;129(1):160-1. https://doi.org/10.1016/j.jaci.2011.10.046 PMid:22196528

15. Intanny VA, Putra NA. Studi eksperimen peningkatan literasi media sosial humas pemerintah daerah (Experimental study 
to improve social media literacy for local government public relations). J IPTEK-KOM. 2019;21(2):109.

16. Czarnowicki T, Krueger JG, Guttman-Yassky E. Skin barrier and immune dysregulation in atopic dermatitis: An evolving story with important clinical implications. J Allergy Clin Immunol Pract. 2014;2(4):371-9. https://doi.org/10.1016/j. jaip.2014.03.006

PMid:25017523

17. Nowicka D, Grywalska E. The role of immune defects and colonization of Staphylococcus aureus in the pathogenesis of atopic dermatitis. Anal Cell Pathol (Amst). 2018;2018:1956403. https://doi.org/10.1155/2018/1956403

PMid:29854575

18. Kay AB. Allergy and allergic diseases. First of two parts. $N$ Engl J Med. 2001;344(1):30-7. https://doi.org/10.1056/
NEJM200101043440106

PMid:11136958

19. AibaS, ManomeH, YoshinoY, TagamiH.Alterationintheproduction of IL-10 and IL-12 and aberrant expression of CD23, CD83 amd CD86 by monocytes or monocyte-derived dendritic cells from atopic dermatitis patients. Exp Dermatol. 2003;12(1):86-95. https://doi.org/10.1034/j.1600-0625.2003.120111.x PMid:12631251

20. Cookson $\mathbf{W}$. The immunogenetics of asthma and eczema: A new focus on the epithelium. Nat Rev Immunol. 2004;4(12):978-88. PMid:15573132

21. Yusriana Y. Antibacterial activity test of earthworm (Lumbricus rubellus) extract against the growth of Staphylococcus aureus. J Surya Med. 2018;12(80):137-45. 